\title{
Pengaruh Citra Perguruan Tinggi dan Kualitas Jasa Terhadap Minat Beli di Universitas Muhammadiyah Gresik Melalui Kepercayaan sebagai Variabel Intervening (Studi Kasus di Universitas Muhammadiyah Gresik)
}

\author{
Eva Desembrianita ${ }^{1}$, Megawati Munir Nur $^{2}$, Suyoto $^{3}$, Malikul Adil $^{4}$, Mahjudin $^{5}$ \\ 1,2,3,4 Program Studi Magister Manajemen, Universitas Muhammadiyah Gresik \\ Email: ${ }^{1}$ evadesse@umg.ac.id
}

\begin{abstract}
This study aims to determine the effect of higher education image and service quality on purchase intention through trust as an intervening variable. This study uses a quantitative approach. The population used in this study were prospective students in Gresik district. The sample size was 100 respondents, using purposive sampling based on certain criteria. The analytical tool used in this research is the SPSS 15 for Windows analysis program. The results of this study indicate that the variables image of higher education and service quality together have a positive and significant effect on buying interest. Based on the analysis, the variables of higher education image and service quality have an indirect effect on buying interest throught trust. However, the coefficient value of the total influence on the image of higher education is smaller, namely 0.161 when compared to the service quality of 0.368 greater.
\end{abstract}

Keywords: Higher education image, Service quality, Trust, Purchase intention.

\begin{abstract}
Abstrak
Penelitian ini bertujuan untuk mengetahui pengaruh citra perguruan tinggi dan kualitas jasa terhadap minat beli melalui kepercayaan sebagai variabel intervening. Penelitian ini menggunakan pendekatan kuantitatif. Populasi yang digunakan dalam penelitian ini adalah calon mahasiswa yang ada di kabupaten Gresik. Jumlah sampel sebanyak 100 orang dengan menggunakan purposive sampling berdasarkan kriteria-kriteria tertentu. Alat analisis yang digunakan dalam penelitian ini yaitu program analisis SPSS 15 for Windows. Hasil penelitian menunjukkan bahwa variabel citra perguruan tinggi dan kualitas jasa secara bersama-sama berpengaruh positif dan signifikan terhadap minat beli. Berdasarkan hasil analisis, variabel citra perguruan tinggi dan kualitas jasa berpengaruh secara tidak langsung terhadap minat beli melalui kepercayaan. Namun, nilai koefisien pengaruh total citra perguruan tinggi lebih kecil yaitu 0,161 jika dibandingkan dengan kualitas jasa 0,368 yang lebih besar.
\end{abstract}

Kata kunci: Citra perguruan tinggi, Kualitas jasa, Kepercayaan, Minat beli.

\section{Pendahuluan}

Saat ini, Indonesia memasuki kondisi pasar global yang semakin kompetitif. Perkembangan dunia pendidikan yang semakin tinggi senantiasa menjadi tuntutan bagi masyarakat untuk terus menempuh pendidikan ke jenjang yang lebih tinggi. Dalam kondisi seperti ini, lembaga pendidikan dituntut untuk terus mencari strategi atau alternatif yang dapat diterapkan supaya dapat bersaing secara kompetitif dengan para kompetitor. Keunggulan kompetitif sangat diperlukan bagi perusahaan yang ingin sukses di pasar. Oleh karena itu, faktor utama yang menentukan masa depan suatu perusahaan yaitu bagaimana keputusan manajemen tentang produk atau jasa yang ditawarkan kepada konsumen.

Persaingan sektor pendidikan di kalangan perguruan tinggi saat ini cukup ketat. Hal ini disebabkan oleh banyaknya perguruan tinggi negeri (PTN) dan swasta (PTS) yang berlomba-lomba dalam memperebutkan pasar untuk menarik minat calon mahasiswa baru. Banyak perguruan tinggi yang melakukan berbagai kegiatan yang bersifat edukatif maupun amal untuk menarik simpati dan supaya lebih dikenal masyarakat dan menarik minat calon mahasiswa. 
Menurut data Badan Penelitian dan Pembangunan (Balitbang) Kemdiknas (2003), tercatat ada 47 Universitas Muhammadiyah di Indonesia, salah satunya yaitu Universitas Muhammadiyah Gresik. Kampus Universitas Muhammadiyah Gresik berlokasi di Jawa Timur, tepatnya kota Gresik. Berdasarkan Surat Keputusan hasil dari Pimpinan Daerah Muhammadiyah Kabupaten Gresik Majelis Pendidikan Pengajaran dan Kebudayaan Nomor: E.1/017-V/1980 bahwa tanggal 25 Mei 1980 merupakan awal berdirinya kampus Universitas Muhammadiyah Gresik yang diresmikan dilakukan oleh Bupati Kabupaten Gresik Bapak Kolonel Wasiadji, SH yang juga sebagai pelindung. Hingga saat ini Universitas Muhammadiyah Gresik memiliki gedung baru 9 lantai yang telah diresmikan oleh wakil gubernur jawa timur Saifullah Yusuf pada hari Jumat tanggal 1 April tahun 2016.

\begin{tabular}{|c|c|c|c|c|c|c|}
\hline No & Program Studi & $\begin{array}{l}\text { Tahun } \\
\text { Akademik } \\
\text { 2015/2016 }\end{array}$ & $\begin{array}{l}\text { Tahun } \\
\text { Akademik } \\
\text { 2016/2017 }\end{array}$ & $\begin{array}{l}\text { Tahun } \\
\text { Akademik } \\
\text { 2017/2018 }\end{array}$ & $\begin{array}{l}\text { Tahun } \\
\text { Akademik } \\
\text { 2018/2019 }\end{array}$ & $\begin{array}{l}\text { Tahun } \\
\text { Akademik } \\
\text { 2019/2020 }\end{array}$ \\
\hline 1 & S1 Agroteknologi & 33 & 33 & 18 & 46 & 105 \\
\hline 2 & S1 Akuntansi & 140 & 139 & 126 & 130 & 529 \\
\hline 3 & S1 Budidaya Perikanan & 17 & 15 & 13 & 19 & 49 \\
\hline 4 & S1 Hukum & & 2 & 18 & 34 & 73 \\
\hline 5 & S1 Hukum Keluarga & - & - & - & - & - \\
\hline 6 & S1 Kewirausahaan & & & 9 & 31 & 62 \\
\hline 7 & S1 Manajemen & 224 & 279 & 251 & 304 & 991 \\
\hline 8 & S1 Pendidikan Agama Islam & 21 & 13 & 68 & 45 & 149 \\
\hline 9 & S1 Pendidikan Bahasa Inggris & 42 & 38 & 44 & 52 & 202 \\
\hline 10 & $\begin{array}{l}\text { S1 Pendidikan Guru Sekolah } \\
\text { Dasar }\end{array}$ & 62 & 87 & 64 & 93 & 360 \\
\hline 11 & $\begin{array}{l}\text { S1 Pendidikan Islam Anak Usia } \\
\text { Dini }\end{array}$ & & 4 & 7 & 20 & 41 \\
\hline 12 & S1 Pendidikan Matematika & 34 & 30 & 24 & 27 & 133 \\
\hline 13 & S1 Psikologi & 31 & 48 & 50 & 74 & 219 \\
\hline 14 & S1 Teknik Elektro & 35 & 70 & 46 & 81 & 212 \\
\hline 15 & S1 Teknik Industri & 210 & 245 & 176 & 173 & 693 \\
\hline 16 & S1 Teknik Informatika & 78 & 78 & 86 & 83 & 343 \\
\hline 17 & S1 Teknik Konstruksi Perkapalan & & & 4 & 13 & 33 \\
\hline 18 & S1Profesi Pendidikan Guru & - & - & - & - & 26 \\
\hline 19 & S2 Magister Bahasa Inggris & & & 18 & 11 & 24 \\
\hline 20 & S2 Magister Manajemen & & 15 & 11 & 15 & 28 \\
\hline 21 & Ilmu Gizi & - & - & - & - & 63 \\
\hline 22 & Kesehatan Masyarakat & - & - & - & - & 43 \\
\hline 23 & Ilmu Keperawatan & - & - & - & - & 57 \\
\hline 24 & Bidan Pendidik & - & - & - & - & 2 \\
\hline 25 & Farmasi & - & - & - & - & 163 \\
\hline 26 & Fisioterapi & - & - & - & - & 17 \\
\hline 27 & Kebidanan & - & - & - & - & 40 \\
\hline 28 & Profesi Ners & - & - & - & - & 10 \\
\hline 29 & Tekhnologi Pangan & - & - & - & - & 3 \\
\hline 30 & Agribisnis & - & - & - & - & 12 \\
\hline 31 & Teknik Kimia & - & - & - & - & 23 \\
\hline \multirow[t]{2}{*}{32} & Teknik Sipil & - & - & - & - & 8 \\
\hline & TOTAL & 927 & 1.096 & 1.033 & 1.251 & 4.713 \\
\hline
\end{tabular}

Universitas Muhammadiyah Gresik adalah salah satu perguruan tinggi swasta di Gresik yang tergolong banyak peminatnya. Terdapat beberapa program studi yang selalu menjadi favorit atau unggulan di Universitas Muhammadiyah Gresik yaitu: S1 Manajemen, Akuntansi, PGSD, teknik industri dan teknik informatika. Banyaknya jumlah peminat calon mahasiswa akan berpengaruh besar terhadap peningkatan jumlah mahasiswa dan akan mempengaruhi minat pembelian di Universitas Muhammadiyah Gresik. Berdasarkan data yang didapat dari BAA (Biro Administrasi Akademik) 
Universitas Muhammadiyah Gresik sampai tahun 2019 tercatat ada 22 prodi yang ditabelkan pada Tabel 1.

Berdasarkan data tabel diatas, dapat dijelaskan bahwa tedapat 32 program studi di Universitas Muhammadiyah Gresik. Program studi yang paling banyak peminatnya yaitu S1 Manajemen berada diposisi terbanyak yaitu dengan jumlah 304 pada tahun 2019 dan terus mengalami kenaikan pada tahun 2020 dengan jumlah 991. Kemudian setelah S1 Manajemen ada program studi Teknik Industri dengan jumlah mahasiswa sebanyak 693 pada tahun 2020. Kemudian program studi Akuntansi yang terus bertambah peminatnya sejumlah 529 dan teknik informatika 343 mahasiswa. Keempat program studi tersebut selalu menjadi prodi unggulan di Universitas Muhammadiyah Gresik.

Dengan meningkatnya persaingan ketat antar Perguruan Tinggi di Indonesia, membuat setiap perguruan tinggi berupaya mendapatkan mahasiswa sebanyak-banyaknya. Sehingga hal ini menjadi hal yang penting dan harus diprioritaskan untuk mengetahui apa alasan konsumen menjadi tertarik dan minat serta memiliki keyakinan untuk memutuskan memilih Perguruan Tinggi tersebut. Dengan memahami alasan minat beli calon mahasiswa dalam memilih Perguruan Tinggi akan mempermudah suatu Perguruan Tinggi untuk menerapkan strategi apa yang seharusnya dilakukan untuk menarik minat calon mahasiswa.

Banyak faktor yang mempengaruhi minat beli, salah satunya citra dan kualitas jasa. Citra perusahaan yang baik akan dapat mempengaruhi minat beli konsumen dalam membeli suatu produk atau jasa [1]. Demikian juga dengan penelitian yang dilakukan Lubis dan Hidayat [2] yang menyebut bahwa Citra perusahaan yang baik dan harga terjangkau akan berdampak pada minat beli konsumen. Pentingnya citra positif suatu perusahaan, sehingga perusahaan perlu mengembangkan dan membangun citra positif agar dapat bersaing untuk menghadapi persaingan di dunia bisnis [3].

Sung dan Yang [4] menjelaskan bahwa saat ini citra perusahaan yang baik akan berpengaruh positif terhadap suatu perusahaan. Sebuah perguruan tinggi dapat membangun keterikatan emosional yang positif jika membuat calon mahasiswa merasa tertarik dan mengembangkan hubungan dengan mereka. Penelitian tentang citra sebuah perguruan tinggi belum banyak dilakukan, oleh karena itu topik ini sangat menarik untuk diteliti. Pernyataan tersebut juga di benarkan oleh Sung dan Yang bahwa sampai saat ini belum banyak penelitian tentang citra perusahaan yang berkaitan dengan perguruan tinggi, sedangkan sejumlah studi pemasaran telah dikhususkan untuk topik tersebut.

Selain citra Perguruan Tinggi, faktor yang mempengaruhi minat beli konsumen yaitu kualitas jasa atau pelayanannya [1]. Setiap perusahaan khususnya yang bergerak di bidang jasa harus memprioritaskan kualitas pelayanan yang baik dan dapat memahami keinginan serta kebutuhan konsumen karena pada bidang jasa yang dihasilkan adalah manfaatnya yang langsung dirasakan oleh para konsumen [1]. Kualitas pelayanan yang baik adalah salah satu faktor penting dalam menentukan minat pembelian [5].Kualitas layanan dikatakan baik jika layanan yang diberikan perusahaan mampu memuaskan pelanggannya.

Perguruan tinggi yang mampu bersaing yaitu perguruan tinggi yang dapat menyediakan produk jasa yang berkualitas. Ketatnya persaingan antar perguruan tinggi yang membuat suatu perguruan tinggi harus terus melakukan perbaikan, terutama dalam segi pelayanan jasa yang bermutu, agar seluruh jasa yang ditawarkan mendapat tempat di mata masyarakat. Sebab salah satu alasan konsumen mengambil keputusan untuk melanjutkan studi di perguruan tinggi yaitu dari kualitas jasanya. Supranto dan Limakrisna [6] juga menjelaskan bahwa "untuk memenangkan persaingan perusahaan harus mampu menghasilkan produk yang mutunya lebih baik, harganya lebih murah, dan kualitas pelayanan lebih baik jika dibandingkan dengan pesaingnya".

Ketika suatu perusahaan sudah memiliki citra dan kualitas yang baik, maka akan timbul rasa percaya dibenak konsumen. Menurut Amanah, dkk. [7], sebuah kepercayaan harus dijadikan sebagai komponen utama dalam strategi pemasaran suatu perusahaan untuk menciptakan hubungan pelanggan yang baik.

Berdasarkan latar belakang diatas, maka peneliti tertarik untuk meneliti lebih lanjut mengenai citra perguruan tinggi, dan kualitas jasa yang merupakan strategi yang baik untuk mempengaruhi minat beli konsumen. Maka dari itu, peneliti melakukan penelitian yang berjudul Pengaruh Citra Perguruan Tinggi dan Kualitas Jasa Terhadap Minat Beli di Universitas Muhammadiyah Gresik Melalui Kepercayaan Sebagai Variabel Intervening. 


\section{Metode}

\section{Desain Penelitian}

Penelitian ini menggunakan pendekatan kuantitatif. Penelitian kuantitatif adalah jenis penelitian yang menghasilkan penemuan-penemuan yang dapat dicapai (diperoleh) dengan menggunakan prosedur-prosedur statistik atau cara lain dari kuantifikasi atau pengukuran [8]. Penelitian kuantitatif adalah penelitian yang lebih menekankan pada angka-angka serta tekhnik analisisnya mengunakan statistik yang dibantu dengan program SPSS.

\section{Populasi dan sampel}

Populasi adalah wilayah generalisasi beupa subjek atau objek yang diteliti untuk dipelajari dan diambil kesimpulan [9]. Populasi dalam penelitian ini adalah calon mahasiswa yang berminat kuliah di Universitas Muhammadiyah Gresik. Sedangkan sampel dalam penelitian yaitu bejumlah 100 orang. Dalam penelitian ini jumlah populasi tidak diketahui secara pasti dan tersebar, maka penentuan jumlah sampel yang akan digunakan dalam penelitian ini menggunakan metode Roscoe (1975) yang dikutip Sekaran [10] bahwa acuan umum dalam penentuan jumlah sampel.

$$
\begin{array}{ll}
\text { Perhitungan: } & \mathrm{n}=\text { Jumlah Variabel } \times 25 \\
& \mathrm{n}=4 \times 25 \\
\mathrm{n} & =100 \text { orang }
\end{array}
$$

Teknik sampling dalam penelitian ini yaitu menggunakan purposive sampling. Menurut Nursiyono [11] purposive sampling adalah teknik sampling yang hanya ditentukan berdasarkan kriteria-kriteria tertentu, pemikiran atau pengetahuan pengambil sampel.

\section{Metode Pengumpulan Data}

Data yang digunakan dalam penelitian ini diperoleh dari sumber pertama baik individu maupun perseorangan dari hasil wawancara langsung atau kuisioner berupa sebuah pertanyaan dengan pemberian bobot angka terendah sampai tertinggi. Data yang sudah terkumpul kemudian dilakukan pengukuran dan pemberian skor. Skala pengukuran yang digunakan dalam penelitian ini yaitu skala likert. Skala likert digunakan untuk mengkur sikap, pendapat, persepsi seseorang atau sekelompok orang tentang fenomena sosial [12].

\section{Teknik Analisis Data}

Alat analisis yang digunakan dalam penelitian ini menggunakan alat bantu program analisis SPSS 15 for Windows. Alat analisis yang digunakan dalam penelitian ini yaitu analisis path (analisis jalur). Sebelum di analisis menggunakan analisis path, data di uji dengan: Uji Instrumen yaitu, a) uji validitas dan b) uji reliabilitas. 


\section{Definisi Operasional Variabel}

Tabel 2. Definisi Variabel dan Indikator

\begin{tabular}{|c|c|c|c|}
\hline No. & Variabel & Definisi Variabel & Indikator \\
\hline 1 & Citra Perguruan Tinggi (X1) & $\begin{array}{l}\text { Aaker dan Biel [13] } \\
\text { Citra memiliki peranan } \\
\text { penting dalam } \\
\text { perkembangan suatu } \\
\text { perusahaan, karena } \\
\text { menyangkut reputasi dan } \\
\text { kepercayaan yang kemudian } \\
\text { menjadi pedoman bagi } \\
\text { konsumen untuk mencoba } \\
\text { dan menggunakan suatu } \\
\text { produk barang atau jasa. }\end{array}$ & $\begin{array}{l}\text { a. Popularitas perusahaan } \\
\text { b. Jaringan perusahaan } \\
\text { c. Kredibilitas perusahaan } \\
\text { d. Reputasi Perusahaan }\end{array}$ \\
\hline 2 & Kualitas Jasa (X2) & $\begin{array}{l}\text { Tjiptono [14] } \\
\text { definisi Kualitas Pelayanan } \\
\text { berpusat pada upaya } \\
\text { pemenuhan kebutuhan dan } \\
\text { keinginan pelanggan serta } \\
\text { ketepatan penyampaiannya } \\
\text { untuk mengimbangi harapan } \\
\text { pelanggan. }\end{array}$ & $\begin{array}{l}\text { a. Reliabilitas (reliability) } \\
\text { b.Daya tanggap } \\
\quad \text { (responsiveness) } \\
\text { c. Jaminan (assurance) } \\
\text { d.Empati (empathy) } \\
\text { e. Bukti fisik (tangible) }\end{array}$ \\
\hline 3 & Kepercayaan (Z) & $\begin{array}{l}\text { Mowen \& Minor [15] } \\
\text { Kepercayaan konsumen } \\
\text { (consumer beliefs) adalah } \\
\text { "semua pengetahuan yang } \\
\text { dimiliki konsumen dan } \\
\text { semua kesimpulan yang } \\
\text { dibuat konsumen tentang } \\
\text { suatu objek, atribut dan } \\
\text { manfaatnya". }\end{array}$ & $\begin{array}{l}\text { a. Objek } \\
\text { b.Atribut } \\
\text { c. Manfaat }\end{array}$ \\
\hline 4 & Minat Beli (Y) & $\begin{array}{l}\text { Kotler dan Keller [16] } \\
\text { Minat Beli adalah "sebuah } \\
\text { perilaku konsumen dimana } \\
\text { konsumen mempunyai } \\
\text { keinginan dalam membeli } \\
\text { atau memilih suatu produk, } \\
\text { berdasarkan pengalaman } \\
\text { dalam menggunakan dan } \\
\text { mengkonsumsi atau bahkan } \\
\text { menginginkan suatu } \\
\text { produk". }\end{array}$ & $\begin{array}{l}\text { a.Kesadaran (Awareness) } \\
\text { b.Pengetahuan (Knowledge) } \\
\text { c.Menyukai (Liking) } \\
\text { d.Pilihan (Preference) } \\
\text { e.Keyakinan (Conviction) }\end{array}$ \\
\hline
\end{tabular}




\section{Hasil dan Pembahasan}

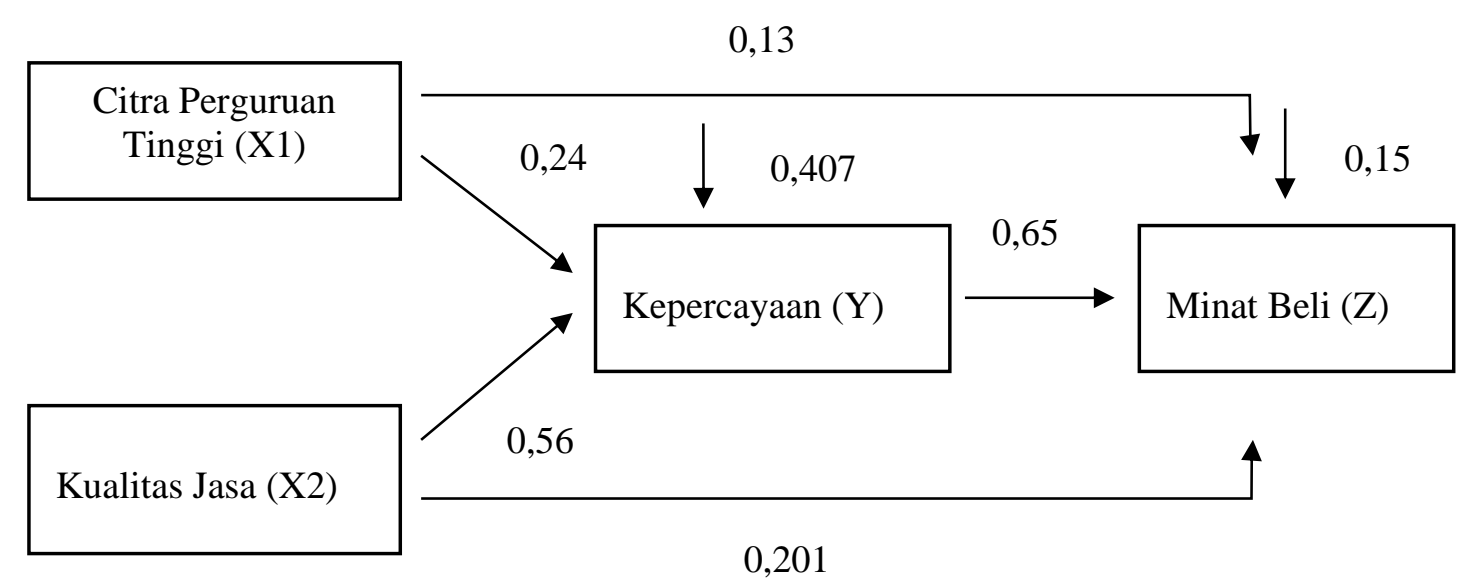

Gambar 1. Persamaan Struktural

Hasil Persamaan Struktural

$Y=0,247 X 1+0,565 X 2+0,407$

$Z=0,138 X 1+0,201 X 2+0,652 Z+0,153$

\section{Hasil Analisis Jalur dan Hipotesis}

1. Berdasarkan perhitungan analisis jalur diatas pengaruh tidak langsung citra perguruan tinggi (X1) terhadap minat beli $(\mathrm{Z})$ melalui kepercayaan $(\mathrm{Y})$ dengan mengalikan pengaruh $\mathrm{X} 1 \mathrm{ke} \mathrm{Y}$ dengan $\mathrm{Y}$ ke $Z$, yaitu: $X 1$ terhadap $Z$ melalui $Y=(0,247 \times 0,652)=0,161$. Serta hasil dari koefisien pengaruh langsung $X 1$ terhadap $Z=0,138$. Jadi besarnya pengaruh tidak langsung variabel citra perguruan tinggi (X1) terhadap minat beli $(Z)$ sebesar 0,161 dan pengaruh langsung variabel citra perguruan tinggi (X1) terhadap minat beli $(\mathrm{Z})$ adalah sebesar 0,138 . Kemudian untuk pengaruh total X1 terhadap $\mathrm{Z}$ yakni: total pengaruh tidak langsung ditambah total pengaruh langsung $=0,161+0,138$ $=0,299$. Berdasarkan hasil atas perhitungan analisis jalur tersebut, maka bisa disimpulkan bahwa pengaruh tidak langsung citra perguruan tinggi (X1) terhadap minat beli (Z) nilainya lebih besar jika dibandingkan dengan pengaruh langsung citra perguruan tinggi (X1) terhadap minat beli (Z). Maka dari itu, karena pengaruh tidak langsung nilainya lebih besar daripada pengaruh langsung, sehingga hipotesis 6 "citra perguruan tinggi terhadap minat beli melalui kepercayaan" terbukti. Dalam hal ini H6 diterima dan H0 ditolak.

2. Berdasarkan hasil dari penghitungan pengaruh tidak langsung variabel kualitas jasa (X2) terhadap minat beli $(\mathrm{Z})$ melalui kepercayaan $(\mathrm{Y})$ berdasarkan hasil diatas dengan mengalikan pengaruh $\mathrm{X} 2 \mathrm{ke}$ $\mathrm{Y}$ dengan $\mathrm{Y}$ ke $\mathrm{Z}$ yaitu sebesar: $0,565 \times 0,652=0,368$ serta hasil dari koefisien $\mathrm{X} 2$ terhadap $\mathrm{Z}=$ 0,201 . Jadi besarnya pengaruh tidak langsung kualitas jasa (X2) terhadap minat beli (Z) adalah sebesar 0,368 . Sedangkan pengaruh total keseluruhan yang diberikan $\mathrm{X} 2$ terhadap $\mathrm{Z}$ yakni: total pengaruh tidak langsung ditambah total pengaruh langsung $=0,368+0,201=0,569$. Bedasarkan hasil perhitungan tersebut, dapat disimpulkan bahwa pengaruh tidak langsung kualitas jasa terhadap minat beli lebih besar dibandingkan pengaruh langsung kualitas jasa terhadap minat beli melalui kepercayaan. Artinya, karena pengaruh tidak langsung lebih besar daripada pengaruh langsung sehingga hipotesis 7 "kualitas jasa terhadap minat beli melalui kepercayaan" dalam penelitian ini terbukti. Hal ini berarti $\mathrm{H} 0$ ditolak dan $\mathrm{H} 7$ diterima.

3. Hasil pengolahan data pengaruh langsung variabel citra perguruan tinggi terhadap variabel kepercayaan yang ditabelkan pada Tabel 3. 
Tabel 3. Pengaruh Langsung Citra Perguruan Tinggi Terhadap Kepercayaan

\begin{tabular}{|c|c|c|c|c|c|c|}
\hline \multirow[b]{2}{*}{ Model } & & \multicolumn{2}{|c|}{$\begin{array}{l}\text { Unstandardized } \\
\text { Coefficients }\end{array}$} & \multirow{2}{*}{$\begin{array}{l}\text { Standardized } \\
\text { Coefficients } \\
\text { Beta }\end{array}$} & \multirow{2}{*}{$\begin{array}{l}\mathrm{T} \\
\mathrm{B} \\
\end{array}$} & \multirow{2}{*}{$\begin{array}{r}\text { Sig. } \\
\text { Std. Error }\end{array}$} \\
\hline & & $\mathrm{B}$ & Std.Error & & & \\
\hline \multirow[t]{3}{*}{1} & (Constant) & -.618 & 1.031 & & -.600 & .550 \\
\hline & Citra & .227 & .092 & .247 & 2.468 & .015 \\
\hline & Kualitas Jasa & .419 & .074 & .565 & 5.646 & .000 \\
\hline
\end{tabular}

a Dependent Variable: Kepercayaan

Berdasarkan Tabel 3, diketahui besarnya angka t hitung variabel citra adalah 2,468 $>$ 1,98472 dan nilai signifikansi sebesar $0,015<0,05$. Dengan nilai t hitung lebih besar dari t tabel dan signifikansi di bawah 0,05 maka hal tersebut menunjukkan bahwa citra memiliki pengaruh yang signifikan terhadap kepercayaan. Hal ini berarti H0 ditolak dan H1 diterima. Hasil penelitian sependapat dengan penelitian sebelumnya yaitu penelitian yang dilakukan oleh Schifman \& Kanuk [17] bahwa citra yang positif akan membuat konsumen percaya apapun tentang suatu perusahaan.

4. Hasil pengolahan data pengaruh langsung variabel kualitas jasa terhadap variabel kepercayaan yang ditabelkan pada Tabel 4.

Tabel 4. Pengaruh Langsung Kualitas Jasa Terhadap Kepercayaan

\begin{tabular}{|c|c|c|c|c|c|c|}
\hline \multirow[b]{2}{*}{ Mod } & & \multicolumn{2}{|c|}{$\begin{array}{c}\text { Unstandardized } \\
\text { Coefficients }\end{array}$} & \multirow{2}{*}{$\begin{array}{c}\begin{array}{c}\text { Standardized } \\
\text { Coefficients }\end{array} \\
\text { Beta }\end{array}$} & \multirow{2}{*}{$\mathrm{T}$} & \multirow{2}{*}{$\begin{array}{r}\text { Sig. } \\
\text { Std. Error }\end{array}$} \\
\hline & & $\mathrm{B}$ & Std.Error & & & \\
\hline \multirow[t]{3}{*}{1} & (Constant) & -.618 & 1.031 & & -.600 & .550 \\
\hline & Citra & .227 & .092 & .247 & 2.468 & .015 \\
\hline & Kualitas Jasa & .419 & .074 & .565 & 5.646 & .000 \\
\hline
\end{tabular}

a Dependent Variable: Kepercayaan

Berdasarkan tabel diatas, dapat diketahui bahwa besarnya angka t hitung variabel kualitas jasa adalah $5,646>1,98472$ dan nilai signifikansi sebesar $0,000<0,05$. Dengan nilai t hitung lebih besar dari $t$ tabel dan signifikansi di bawah 0,05 maka hal tersebut menunjukkan bahwa kualitas jasa memiliki pengaruh yang signifikan terhadap kepercayaan. Hal ini berarti H0 ditolak dan $\mathrm{H} 2$ diterima. Hasil penelitian ini sejalan dengan penelitian sebelumnya yang dilakukan oleh Irawati [18] bahwa kualitas layanan berpengaruh positif terhadap kepercayaan konsumen. Ketika kualitas jasa mampu memberikan kepuasan terhadap konsumen, maka akan timbul persepsi positif lalu konsumen percaya dan muncul minat, kemudian muncul keinginan untuk melakukan pembelian.

5. Hasil pengolahan data pengaruh langsung variabel kepercayaan terhadap variabel minat beli yang ditabelkan pada Tabel 5 .

Tabel 5. Pengaruh Langsung Kepercayaan Terhadap Minat Beli

\begin{tabular}{|c|c|c|c|c|c|c|}
\hline \multirow[b]{2}{*}{ Mode } & & \multicolumn{2}{|c|}{$\begin{array}{c}\text { Unstandardized } \\
\text { Coefficients }\end{array}$} & \multirow{2}{*}{$\begin{array}{c}\begin{array}{c}\text { Standardized } \\
\text { Coefficients }\end{array} \\
\text { Beta }\end{array}$} & \multirow{2}{*}{$\mathrm{T}$} & \multirow{2}{*}{$\begin{array}{r}\text { Sig. } \\
\text { Std. Error }\end{array}$} \\
\hline & & B & Std.Error & & & \\
\hline \multirow[t]{4}{*}{1} & (Constant) & 1.555 & .936 & & 1.661 & .100 \\
\hline & Citra & .187 & .086 & .138 & 2.177 & .032 \\
\hline & Kualitas Jasa & .220 & .078 & .201 & 2.834 & .006 \\
\hline & Kepercayaan & .959 & .092 & .652 & 10.416 & .000 \\
\hline
\end{tabular}

a Dependent Variable: Minat Beli 
Berdasarkan tabel di atas, dapat diketahui bahwa besarnya angka t hitung variabel kepercayaan adalah 10,416 $>1,98498$ dan nilai signifikansi sebesar $0,000<0,05$ Dengan nilai t hitung lebih besar $\mathrm{t}$ tabel dan signifikansi di bawah 0,05 tersebut menunjukkan bahwa kepercayaan memiliki pengaruh yang signifikan terhadap minat beli. Hal ini menununjukkan bahwa $\mathrm{H} 0$ ditolak dan $\mathrm{H} 3$ diterima.

Hubungan kedua variabel tersebut diperkuat dengan penelitian terdahulu yang dilakukan oleh Silva [19] yaitu kepercayaan konsumen memiliki pengaruh yang signifikan terhadap minat pembelian. Keterkaitan antara kepercayaan dan minat beli juga diperkuat penelitian sebelumnya yang dilakukan oleh Schifman \& Kanuk [20] kepercayaan adalah suatu proses seorang individu dalam menyeleksi, mengorganisasikan, dan menterjamahkan stimulus informasi yang datang menjadi suatu gambaran yang mempunyai pengaruh kuat bagi konsumen untuk menentukan minat pembelian.

6. Hasil pengolahan data pengaruh variabel citra perguruan tinggi terhadap variabel minat beli yang ditabelkan pada Tabel 6.

Tabel 6. Pengaruh Langsung Citra Perguruan Tinggi Terhadap Minat Beli

\begin{tabular}{|c|c|c|c|c|c|c|}
\hline \multirow[b]{2}{*}{ Mode } & & \multicolumn{2}{|c|}{$\begin{array}{l}\text { Unstandardized } \\
\text { Coefficients }\end{array}$} & \multirow{2}{*}{$\begin{array}{c}\begin{array}{c}\text { Standardized } \\
\text { Coefficients }\end{array} \\
\text { Beta }\end{array}$} & \multirow{2}{*}{$\begin{array}{l}\mathrm{T} \\
\mathrm{B}\end{array}$} & \multirow{2}{*}{$\begin{array}{r}\text { Sig. } \\
\text { Std. Error }\end{array}$} \\
\hline & & $\mathrm{B}$ & Std.Error & & & \\
\hline \multirow[t]{4}{*}{1} & (Constant) & 1.555 & .936 & & 1.661 & .100 \\
\hline & Citra & .187 & .086 & .138 & 2.177 & .032 \\
\hline & Kualitas Jasa & .220 & .078 & .201 & 2.834 & .006 \\
\hline & Kepercayaan & .959 & .092 & .652 & 10.416 & .000 \\
\hline
\end{tabular}

a Dependent Variable: Minat Beli

Berdasarkan tabel 6 diatas, diketahui besarnya angka thitung variabel citra perguruan tinggi adalah $2,177>1,98498$ dan nilai signifikansi yaitu sebesar $0,032<0,05$. Dengan nilai t hitung lebih besar $\mathrm{t}$ tabel dan signifikansi di bawah 0,05 tersebut menunjukkan bahwa citra perguruan tinggi memiliki pengaruh yang signifikan terhadap minat beli. Hal ini berarti $\mathrm{H} 0$ ditolak dan $\mathrm{H} 4$ diterima.

Keterkaitan antara citra terhadap minat pembelian juga diperkuat dengan penelitian terdahulu yang dilakukan oleh Irana [21] citra yang baik dan harga terjangkau yang ditawarkan berdampak pada keputusan pembelian oleh konsumen. Hasil penelitian menyebutkan secara simultan citra merek dan harga berpengaruh positif dan signifikan terhadap minat pembelian.

7. Hasil pengolahan data pengaruh langsung variabel kualitas jasa terhadap variabel minat beli yang ditabelkan pada Tabel 7.

Tabel 7. Pengaruh Langsung Kualitas Jasa Terhadap Minat Beli

\begin{tabular}{|c|c|c|c|c|c|c|}
\hline \multirow[b]{2}{*}{ Mod } & & \multicolumn{2}{|c|}{$\begin{array}{c}\text { Unstandardized } \\
\text { Coefficients }\end{array}$} & \multirow{2}{*}{$\begin{array}{c}\text { Standardized } \\
\text { Coefficients } \\
\text { Beta } \\
\end{array}$} & \multirow{2}{*}{$\begin{array}{l}\mathrm{T} \\
\mathrm{B}\end{array}$} & \multirow{2}{*}{$\begin{array}{r}\text { Sig. } \\
\text { Std. Errol } \\
\end{array}$} \\
\hline & & B & Std.Error & & & \\
\hline \multirow[t]{4}{*}{1} & (Constant) & 1.555 & .936 & & 1.661 & .100 \\
\hline & Citra & .187 & .086 & .138 & 2.177 & .032 \\
\hline & Kualitas Jasa & .220 & .078 & .201 & 2.834 & .006 \\
\hline & Kepercayaan & .959 & .092 & .652 & 10.416 & .000 \\
\hline
\end{tabular}

a Dependent Variable: Minat Beli

Berdasarkan tabel diatas, dapat diketahui bahwa besarnya angka t hitung variabel kualitas jasa adalah $2,834>1,98498$ dan nilai signifikansi sebesar $0,006<0,05$. Dengan nilai t hitung lebih besar $t$ tabel dan signifikansi di bawah 0,05 tersebut menunjukkan bahwa kualitas jasa memiliki pengaruh yang signifikan terhadap minat beli. Hal ini berarti $\mathrm{H} 0$ ditolak dan $\mathrm{H} 5$ diterima. 
Hubungan antara variabel kualitas jasa dan minat pembelian diperkuat dengan penelitian terdahulu oleh Subarjo [22] yaitu kualitas jasa berpengaruh positif terhadap minat pembelian konsumen secara simultan.

\section{Kesimpulan}

Berdasarkan hasil pengujian ketujuh hipotesis yang telah diajukan dalam penelitian ini, dapat ditarik kesimpulan yaitu:

1. Hasil pengujian hipotesis penelitian menunjukan bahwa citra berpengaruh secara langsung terhadap kepercayaan calon mahasiswa Universitas Muhammadiyah Gresik.

2. Hasil pengujian hipotesis penelitian menunjukan bahwa kualitas jasa berpengaruh secara langsung terhadap kepercayaan calon mahasiswa Universitas Muhammadiyah Gresik.

3. Hasil dari pengujian hipotesis penelitian menunjukan bahwa kepercayaan berpengaruh secara langsung terhadap minat beli calon mahasiswa Universitas Muhammadiyah Gresik.

4. Hasil dari pengujian hipotesis penelitian menunjukan bahwa citra berpengaruh secara langsung terhadap minat beli calon mahasiswa Universitas Muhammadiyah Gresik.

5. Hasil dari pengujian hipotesis penelitian menunjukan bahwa kualitas jasa berpengaruh secara langsung terhadap minat beli calon mahasiswa Universitas Muhammadiyah Gresik.

\section{Referensi}

[1] M. Mutmainnah, "Pengaruh Kualitas Layanan Dan Citra Perusahaan Terhadap Kepuasan Dan Loyalitas Nasabah," Jurnal Manajemen Dan Pemasaran Jasa, vol. 10, no. 2, pp. 201-216, 2018.

[2] D. I. D. Lubis and R. Hidayat, "Pengaruh Citra Merek dan Harga terhadap Keputusan Pembelian pada Sekolah Tinggi Ilmu Manajemen Sukma Medan," Jurnal Ilman: Jurnal Ilmu Manajemen, vol. 5, no. 1, 2019.

[3] A. G. Rizki, K. Hidayat, and L. D. Rahma Devita, "Pengaruh citra merek dan harga terhadap keputusan pembelian pada e-commerce Shopee Indonesia (Survei pada mahasiswa S1 fakultas Ilmu Administrasi Universitas Brawijaya angkatan 2015/2016 dan 2016/2017 yang membeli barang secara online di e-commerce)," Jurnal Administrasi Bisnis, vol. 72, no. 2, pp. 49-56, 2019.

[4] M. Sung and S.-U. Yang, "Toward the model of university image: The influence of brand personality, external prestige, and reputation," Journal of public relations research, vol. 20, no. 4, pp. 357-376, 2008.

[5] L. Lahindah and R. A. Siahaan, "The Influence of Product Innovation and Service Quality to Buying Decision and the Impact to Repeat Buying at Progo Road Bandung," The Asian Journal of Technology Management, vol. 11, no. 2, pp. 118-124, 2018.

[6] J. Supranto and N. Limakrisna, "Perilaku Konsumen dan Strategi Pemasaran untuk Memenangkan Strategi Bisnis," ed: Kharisma Putra Utama. Jakarta, 2011.

[7] D. Amanah, R. Hurriyati, V. Gaffar, L. A. Wibowo, D. A. Harahap, and Y. Saragih, "Which is More Influential in Online Purchasing Decisions: Price or Trust," in 1st International Conference on Islamic Economics, Bussiness and Philanthropy, 2017, pp. 798-803.

[8] V. W. Sujarweni, "Metodologi penelitian bisnis dan ekonomi," 2015.

[9] A. Neolaka, "Metode penelitian dan statistik," Bandung: PT Remaja Rosdakarya, 2014.

[10] U. Sekaran, "Metode Riset Bisnis," Jakarta: Salemba Empat, 2006.

[11] J. A. Nursiyono, "Kompas Teknik Pengambilan Sampel," Bogor: In Media, 2014.

[12] A. Neolaka, "Metode penelitian dan statistik," Bandung: PT Remaja Rosdakarya, 2014.

[13] D. A. Aaker, "Manajemen Pemasaran Strategis (Strategic Market Management)," Penerbit Salemba Empat: Jakarta, 2013.

[14] F. Tjiptono and G. Chandra, "Service, Quality dan Satisfaction. Yogyakarta; Andi," Jurnal of Business and Management Sciences, vol. 4, no. 4, pp. 76-81, 2004.

[15] J. Mowen, "C. dan Michael Minor. 2001 Perilaku Konsumen," Jakarta: Erlangga.

[16] P. Kotler, "Keller.(2012) Marketing Management," ed: New Jersey: Pearson Prentice Hall. Inc. 
[17] L. G. Schiffman and L. L. Kanuk, "Consumer behavior," Upper Saddle River, NJ, 2007.

[18] R. Irawati, "Pengaruh Ketidakpuasan Konsumen dan Kebutuhan Mencari Variasi terhadap Keputusan Perpindahan Merek Pembalut Wanita (Studi pada Mahasiswi Fakultas Ekonomi Universitas Andalas Padang)," Manajemen S-1, vol. 1, no. 1, 2013.

[19] A. G. Silva, M. Canavari, and A. E. Wander, "Consumers intention towards purchasing IP certified beans: an analysis using the theory of planned behaviour (TPB)," Embrapa Arroz $e$ Feijão-Artigo em periódico indexado (ALICE), 2017.

[20] L. G. Schiffman and L. L. Kanuk, "Consumer Behavioral," ed: New Jersey: Pearson, 2010.

[21] D. I. D. Lubis and R. Hidayat, "Pengaruh Citra Merek dan Harga terhadap Keputusan Pembelian pada Sekolah Tinggi Ilmu Manajemen Sukma Medan," Jurnal Ilman: Jurnal Ilmu Manajemen, vol. 5, no. 1, 2019.

[22] S. Subarjo, "KEPUASAN KERJA TERHADAP INTENSI TURNOVER KARYAWAN PADA PERUSAHAAN WAJAR YOGYAKARTA," Jurnal Analisis Bisnis Ekonomi, vol. 12, no. 1, pp. 63-73, 2014. 